KORNELIA CZERWIŃSKA, IZABELLA KUCHARCZYK The Maria Grzegorzewska University, Warsaw

\title{
Senior citizens losing vision as a challenge to contemporary special education
}

\begin{abstract}
Kornelia Czerwińska, Izabella Kucharczyk, Senior citizens losing vision as a challenge to contemporary special education. Interdisciplinary Contexts of Special Pedagogy, no. 25, Poznań 2019. Pp. 333-351. Adam Mickiewicz University Press. ISSN 2300-391X. DOI: https:/ / doi.org/10.14746/ikps.2019.25.14
\end{abstract}

Acquiring blindness or low vision at the senior age usually results in decreased quality of life due to a decrease in functional performance in the areas of activities of everyday activities, spatial orientation and mobility, physical activity, spending free time and obtaining information. Loss of vision also implies serious emotional consequences, which in the absence of professional therapeutic help and social support can lead to mental health disorders. Research analyses indicate that the level of satisfying rehabilitation needs of seniors who are losing vision is relatively low, and the specificity of their functioning resulting from the coexistence of various health problems is rarely included in support programs. The aim of the article is to indicate areas that have been so far neglected in the rehabilitation of elderly people who have acquired visual impairment and to formulate proposals aimed at increasing the availability and quality of therapeutic services for this social group.

KEY WORDS: vision loss, visual impairment, late adulthood, social support, social security

\section{Introduction}

The dynamic transformations of contemporary social space generate new criteria for the selection and allocation of individuals and demonstrate the need for scientific reflection on the specific needs of 
groups at risk of exclusion and the need to design support activities aimed at increasing their successful participation in social life ${ }^{1}$. Among numerous currently observed changes, which may lead to a significant deepening of problems of marginalization of specific groups, the progressive process of population ageing is particularly noteworthy. The constantly increasing percentage of elderly people in the general social structure entails new problems and tasks for individuals, groups, communities and countries, resulting in a global systemic transformation in all relevant areas of public life ${ }^{2}$. Ensuring proper living conditions and using the potential of people who, in late adulthood, suddenly or gradually acquire disability, become a special challenge.

Psychosocial functioning of adults with disabilities has relatively recently became the subject of interest for special educators ${ }^{3}$. Activities, research and analysis in this scientific subdiscipline focused primarily on childhood, and mainly on issues related to the education system and satisfying special educational and rehabilitation needs related to the type and degree of disability. The departure from the medical paradigm in favour of the biopsychosocial concept of disability led to changes in the understanding of the development conditions of this group of people and activated the tendency to normalization of the environment and social inclusion, as well as guaranteeing a sense of psychophysical well-being, which required the adoption of a full course of life perspective in theoretical and scientific analyses 4 . It was observed that in the late adulthood people with disabilities

${ }^{1}$ G. Dryżałowska, M. Kuleta-Hulboj, A. Naumiuk, M. Skura, A.M. Steinhagen, Inkluzja w perspektywie pedagogiki specjalnej i pedagogiki społecznej. Pytania, konteksty, dyskusje, Wydawnictwo UW, Warsaw 2018, pp. 20-21.

2 Z. Woźniak, Programy i strategie polityki społecznej dla grup ryzyka. Przestanki, cele, narzędzia, praca socjalna, Difin, Warsaw 2019, pp. 208-210.

${ }^{3}$ A. Krause, Wspótczesne paradygmaty pedagogiki specjalnej, Oficyna Wydawnicza „Impuls", Cracow 2010, pp. 50-51.

${ }^{4}$ A. Rakowska, Transformacja pedagogiki specjalnej - próba interpretacji niektórych aspektów ewolucji, [in:] „Uwarunkowania i kierunki rozwoju pedagogiki specjalnej”, ed. B. Antoszewska, Cz. Kosakowski, Wydawnictwo Adam Marszałek, Toruń 2011, p. 9. 
become particularly vulnerable to marginalization and reduced quality of life, and the need to focus educational activities on this age group was emphasized. It has been recognized that the key areas of functioning of senior citizens with disabilities requiring in-depth scientific analyses leading to the development of good support practices includes, among others, shaping healthy habits, spending free time, participation in cultural events as audience and creator, and social participation. It has been postulated to introduce changes into the Polish system of preparing for a profession of special educator in order to equip these specialists with competencies necessary to work with both senior citizens whose disability is innate and those who lost their fitness in elderly age ${ }^{5}$. Despite the undoubted increase in interest in the issue of experiencing disability in late adulthood, this area is still considered one of the most neglected in Polish studies and scientific analyses in the field of special education ${ }^{6}$.

Strategies for using development potential and providing senior citizens with care and support are a common field of research and practice within numerous scientific disciplines 7 . Currently, increasing participation in transdisciplinary research aimed at the real recognition of the health-related and socio-economic situation of elderly people and the development of preventive and support programs allowing for the successful implementation of developmental tasks typical of late adulthood, is becoming a challenge for special education. In gerontological programs embedded in broadly understood social policy, it is considered necessary to closely combine projects aimed at solving problems typical of both elderly people and people with disabilities ${ }^{8}$. Therefore, activities aimed at main-

${ }^{5}$ I. Chrzanowska, Starość z niepetnosprawnościa, [in:] „Człowiek i jego rodzina wobec utraty zdrowia i sprawności”, ed. A. Nowicka, J. Bąbka, Copper Belt Technical College in Lubin, Lubin 2010, p. 103.

${ }^{6}$ I. Chrzanowska, Pedagogika specjalna. Od tradycji do wspótczesności, Oficyna Wydawnicza „Impuls”, Cracow 2015, p. 626.

${ }^{7}$ A. Błachnio, Potencjał osób w starości. Poczucie jakości życia w procesie starzenia się, Wydawnictwo UKW, Bydgoszcz 2019, pp. 30-74.

8 Z. Woźniak, Programy i strategie polityki społecznej dla grup ryzyka. Przestanki, cele, narzędzia, praca socjalna, Difin, Warsaw 2019, p. 230. 
taining the quality of life and securing senior citizens against feelings of loneliness and marginalization, require the active participation of representatives of all sub-disciplines of special education. Due to the fact that visual impairment is the third most frequent chronic disease in elderly people ${ }^{9}$, it is advisable to increase the involvement of educators of people with visual impairment in the creation of national senior-related policy.

\section{Ageing and disability}

Worldwide demographic forecasts estimate that the population will increase by half in 2050 compared to 2000, with a threefold increase in the elderly people population. The largest increase is forecast in the group of people aged 80 and more. In 2030, every third person in the European Union member states will reach the age of 60 and more, while a quarter of the European population will be aged 65 and more ${ }^{10}$. The analyses prepared by the Statistics Poland based on current reports, the results of the Polish Census of 2011 and the demographic forecast for 2014-2050 indicate the occurrence of similar trends in Poland.

In the years 1989-2016, the number of elderly people increased in Poland by almost 3.7 million, including the largest increase, by more than 0.9 million, recorded for the group of 60-64-year-old people. During that time, the percentage of people aged 60 or above in the general population increased by almost 10 percentage points, while the percentage of children and adolescents decreased by approximately 12 percentage points. Almost $18 \%$ of the senior population are people of at least 80 years old. Forecasts indicate a progress of the ageing process of the population, because despite the forecast

${ }^{9}$ R. Stevens-Ratchford, A. Krause, Visually Impaired Older Adults and HomeBased Leisure Activities: The Effects of Person-Environment Congruence, "Journal of Visual Impairment \& Blindness" 2004, no. 98(1), pp. 14-15.

10 Z. Woźniak, Programy i strategie polityki społecznej dla grup ryzyka. Przesłanki, cele, narzędzia, praca socjalna, Difin, Warsaw 2019, p. 208. 
decrease in the population by 4.5 million by 2050 , there will be a systematic increase in the number of people aged 60 and more. At the end of the forecast horizon, the population of people of this age will constitute over $40 \%$ of the total population. It is estimated that in 2050 as much as $42 \%$ of urban residents and $38 \%$ of rural residents will be at least 60 years old. Between 2025 and 2040, the number of people aged 80 and more will double ${ }^{11}$.

Extending the average life expectancy implies the necessity to implement measures to ensure successful ageing understood as maintaining a relatively high level of physical and mental functions, maintaining functional independence, manifesting activity in the public and social sphere, experiencing financial independence, as well as having opportunities for education and self-fulfilment ${ }^{12}$. The basic determinants of successful ageing are closely linked to a sense of well-being and high quality of life, the achievement of which is the main goal of social support and preventive activity among senior citizens ${ }^{13}$. One of the most important factors determining the quality of life in elderly age is health, whose condition determines the ability to independently fulfil the needs and normative implementation of developmental tasks specific to late adulthood ${ }^{14}$.

The results of Eurostat research for 2016 indicate that in Poland a 65-year-old man still has on average of approximately 16 years of

11 Informacja o sytuacji osób starszych na podstawie badań Głównego Urzędu Statystycznego, https://stat.gov.pl/obszary-tematyczne/osoby-starsze/osoby-starsze/in formacja-o-sytuacji-osob-starszych-na-podstawie-badan-glownego-urzedu-statystycz nego,1,2.html [2 April 2019].

12 E. Kościńska, Starzenie się człowieka - zagadnienia ogólne, [in:] „Wybrane formy opieki i pomocy dla seniorów”, ed. E. Kościńska, Wydawnictwo UKW, Bydgoszcz 2013, pp. 23-26.

13 I. Mandrzejewska-Smól, Aktywność edukacyjna i zawodowa osób w wieku emerytalnym w perspektywie pomyślnego starzenia się. Diagnoza wybranych problemów, Wydawnictwo UKW, Bydgoszcz 2018, pp. 31-71. A. Wieczorek, Starość i starzenie się z punktu widzenia wspótczesnego doradcy - geragoga, [in:] „Wielowymiarowość poradnictwa w życiu człowieka", ed. D. Kukla, Difin, Warsaw 2011, p. 418.

14 D. Rynkowska, Rola opiekunów w procesie wsparcia podopiecznych w świetle dziatalności opiekuńczej Polskiego Czerwonego Krzyża, Wydawnictwo URz, Rzeszów 2019, pp. 79-80. 
life ahead, including 8.2 years of healthy life (average number of years without disability), while a woman has 8.9 years in good health condition out of her remaining 20.5 years. According to the results of the European Union Statistics on Income and Living Conditions (EU-SILC) from 2017, 67.7\% of Poles over 60 years of age perceive in themselves long-term health problems or chronic diseases that last (or are expected to last) at least 6 months. Over $46 \%$ of the surveyed senior citizens rated their ability to perform daily activities as seriously or not very seriously limited because of their health condition. Data collected as part of the latest European Health Interview Survey (EHIS) conducted in 2014 demonstrated that chronic diseases occur in most elderly people; only every ninth person did not report such problems. It was found that only every sixth elderly person did not use glasses or contact lenses, while nearly every second senior citizen, despite using correction, experienced difficulty with vision; this phenomenon was noted primarily among the oldest people. In the group of at least 80 years old people, $2 / 3$ of the respondents reported vision problems, of which almost every fifth person declared that they had significant vision problems or did not see at all. In addition, the health condition resulted in the fact that every third person aged 65 and more had difficulty in performing everyday activities related to self-care (going to bed and getting up from the bed, sitting and getting up from the chair, bathing or washing in the shower, dressing and undressing). It should be emphasized that nearly $45 \%$ of elderly people who have problems with basic self-care activities did not receive any help from other people and did not have access to facilities and assistive devices. Furthermore, difficulties in the field of independent and safe movement increasing with age, were recorded. Every third elderly person reported problems in the $500 \mathrm{~m}$ walk without using the help of another person or equipment such as a walking stick, crutch, zimmer frame; difficulties of this type were experienced by every second person aged $70-79$ and nearly $3 / 4$ of the population of people over 80 years of age. Nearly $30 \%$ of people aged $60-69$ had problems to 
ascend and descend the stairs on their own. These problems were declared by more than half of the respondents from the group of $70-79$ years old and almost $80 \%$ of people of 80 years old or older ${ }^{15}$. It is worth noting that the risk of limitation or loss of functional performance by elderly people is particularly high due to the coexistence of numerous disorders. Over $40 \%$ of the Polish senior population suffers from four or more chronic diseases, which contributes to dependence increasing with age, and generates a number of complex problems at the individual, family and community level ${ }^{16}$.

Coexistence of several diseases is relatively common among elderly people who acquire visual impairment. According to data concerning the population of Great Britain, people who have lost their vision are twice as likely to report other somatic or mental illnesses and experience of other permanent dysfunctions. Disorders related to visual impairment are often not reported to a physician by senior citizens in the order of priority, but a detailed analysis of the medical history usually indicates that visual dysfunction leads to complications in other conditions. Approximately $30 \%$ of people reporting themselves as blind or deaf and $69 \%$ of those with both disabilities suffer from at least four other chronic conditions. The dysfunctions most commonly associated with age-related vision impairment include diabetes, hearing loss, dementia syndromes, stroke, depression. The consequences of vision loss and deterioration of health condition resulting from other diseases are complex, interrelated, so they imply the need to integrate medical services and provide elderly people with holistic rehabilitation care ${ }^{17}$.

15 Informacja o sytuacji osób starszych na podstawie badań Głównego Urzędu Statystycznego, https://stat.gov.pl/obszary-tematyczne/osoby-starsze/osoby-starsze/infor macja-o-sytuacji-osob-starszych-na-podstawie-badan-glownego-urzedu-statystyczne go,1,2.html [02 April 2019].

16 D. Rynkowska, Rola opiekunów w procesie wsparcia podopiecznych w świetle dziatalności opiekuńczej Polskiego Czerwonego Krzyża, Wydawnictwo URz, Rzeszów 2019, pp. 83-84.

17 M. Kilian, Następstwa utraty wzroku w starszym wieku, „Człowiek - Niepełnosprawność - Społeczeństwo" 2010, no. 2(12), pp. 89-103. A. Sinclair, B. Ryan, D. Hill, 


\section{Senior citizens losing vision, needs and support}

The population of people acquiring blindness or low vision in late adulthood does not have a homogeneous nature and is characterized by high heterogeneity of possibilities and needs. However, the existing empirical analyses indicate, quite unequivocally, that the loss of vision in this phase leads to a decrease in the quality of life due to experiencing a number of significant difficulties in the basic spheres of psychosocial functioning ${ }^{18}$ Studies comparing the behavioural and emotional adaptation of elderly people with and without visual impairment have demonstrated that age-related vision impairment is associated with other significant losses that increase within a six-year period from vision loss, including future orientation disorders and a decrease in life satisfaction. Acquisition of visual impairment has a negative impact on the course and effects of ageing, and which is most important, increases the risk of mortality ${ }^{19}$.

Visual impairment hinders the performance of everyday activities in an effective and safe manner. Senior citizens with acquired visual impairment declare greater problems in performing self-care activities and tasks related to household management than their peers with good vision. It has been observed that people with visual impairment of over 70 years of age perform everyday activities at a level typical for people of over 90 years of age ${ }^{20}$. The everyday

Sight loss in older people. The essential guide for general practice, The Royal National Institute of Blind People, London 2014, pp. 15-21.

${ }_{18}$ K. Czerwińska, I. Kucharczyk, Nabycie npiepetnosprawności wzroku w późnej dorosłości a jakość ̇̇ycia, „Niepełnosprawność. Dyskursy pedagogiki specjalnej” 2019, no. 34, pp. 131-145. C-W Pan, H. Liu, H-P. Sun, Y. Xu, Increased Difficulties in Managing Stairs in Visually Impaired Older Adults: A Community-Based Survey, "PLoS ONE" 2015, no. 10(11), DOI: 10.1371/journal.pone.0142516, pp. 2-8.

${ }^{19} \mathrm{H}$. Wahl, V. Heyl, Psychosocial adaptation to age-related vision loss: A six-year perspective, "Journal of Visual Impairment \& Blindness" 2001, no. 95, pp. 739-748.

$20 \mathrm{~J}$. Percival, Meeting the needs of older people with visual impairment: Social care or social exclusion?, Thomas Pocklington Trust, London 2003, pp. 1-15. 
activity of the discussed group is also smaller due to problems with spatial orientation and independent movement, especially in terms of ascending the stairs ${ }^{21}$, using public transport and moving in the outdoor environment ${ }^{22}$. Restrictions of mobility are also associated with the risk of injury as a result of falls, to which senior citizens with visual impairment are exposed nearly twice more likely than elderly people without perceptual problems. Importantly, the occurrence of a fall leads to a decrease in motor activity, which results in a decrease in the level of motor performance as a result of weakening of joint stability and muscle strength as well as deterioration of equivalent reactions and loss of normal gait patterns ${ }^{23}$.

Negative consequences of the acquisition of visual impairment are also visible in the field of social participation of senior citizens. Studies comparing the degree of social activity of elderly people with visual impairment and their able-bodied peers have demonstrated that the extent of participation in social life of this group of senior citizens is smaller. These data are alarming because social and public activities are an indicator of a successful course of the ageing process and have a positive impact on broadly understood health. Restrictions that were noted among the respondents concerned mainly voluntary and professional activity (92\%), forms of spending free time $(88 \%)$, housework ( $84 \%)$, socialization (53\%). In addition, subjects with visual impairment experienced a sense of loneliness more often compared to the reference group ${ }^{24}$. The re-

${ }^{21}$ N.N. Hairi, A. Bulgiba, D. Peramalah, I. Mudla, Do older people with visual impairment and living alone in a rural developing country report greater difficulty in managing stairs?, "Preventive Medicine" 2013, no. 56, pp. 8-11.

22 A. Lewicka, Niezależność osób niewidomych, czyli rzeczywistość - oczekiwania utrudnienia, [in:] „Jakość życia a niepełnosprawność. Konteksty psychopedagogiczne", ed. Z. Palak, A. Lewicka, A. Bujnowska, Wydawnictwo UMCS, Lublin 2006, pp. 365-368.

${ }^{23}$ S.R. Lord, S.T. Smith, J.C. Menant, Vision and falls in older people: risk factors and intervention strategies, "Clinics in Geriatric Medicine" 2010, no. 26(4), pp. 569-581.

${ }^{24}$ M.A. Alma, S.F. Van Der Mei, B.J.M. Melis-Dankers, T.G. Van Tilburg, J.W. Groothoff, Suurmeijer T.P.B.M., Participation of the elderly after vision loss, "Disability \& Rehabilitation" 2011, no. 33(1), pp. 63-72, DOI: 10.3109/09638288.2010.488711. 
duced scope of leisure activities has also been confirmed in other scientific analyses ${ }^{25}$, which is worth emphasizing due to the fact that in late adulthood the importance of home activities, recreation, rest and participation in social life increases significantly and directly affects life satisfaction.

Serious effects of vision loss at elderly age occur in the sphere of emotional functioning. These problems are quite often not perceived by specialists, especially in situations where the acquisition of disability is a gradual process associated with the progressive nature of a disease of the visual system ${ }^{26}$. The feelings experienced by blind seniors, such as: uneasiness, irritability, anxiety, despair, feeling of malaise, loss and lifelong change, are difficult to observe due to the specific form of their expression and the mechanisms of denial and repression. The emotional state of these people is also sometimes incorrectly assessed due to low awareness and lack of suitable training of medical staff. Lack of emotional support at the critical moment of diagnosis and the beginning of the adaptation process strengthens the feeling of being not understood and favours mental health disorders, especially depression. Likewise, at the later stages of rehabilitation, the lack of sensitivity to the emotional state of an elderly person and the failure to perceive the affective determinants of their behaviour may lead to incorrect assessments of their needs, level of motivation and expectations from a specialist, and thus reduce the effectiveness of therapeutic interactions. For example, cancelling or shortening a home visit may not necessarily indicate a lack of interest in the offered services, but may result from an unconscious desire to mask malaise accompanied by a wish to maintain contact with the rehabilitator ${ }^{27}$.

${ }^{25}$ R. Stevens-Ratchford, A. Krause, Visually Impaired Older Adults and HomeBased Leisure Activities: The Effects of Person-Environment Congruence, "Journal of Visual Impairment \& Blindness" 2004, no. 98(1), pp. 14-27.

26 S.C. Houde, ed., Vision Loss in Older Adults. Nursing Assessment and Care Management, Springer Publishing Company, New York 2007, pp. 109-130.

$27 \mathrm{~J}$. Percival, Meeting the needs of older people with visual impairment: Social care or social exclusion?, Thomas Pocklington Trust, London 2003, pp. 1-15. 
When determining the rehabilitation needs of senior citizens who are losing vision, it is necessary to assess the functional consequences of visual impairment in a holistic way and recognize their interrelationships, as well as the impact of contextual and environmental factors. For example, problems in the area of spatial orientation and movement will directly have a negative impact on the sphere of social participation of a senior citizen, however, the acquisition of competences that increase mobility will not immediately broaden social contacts, which may have weakened for many different reasons (including emotional problems, mental barriers in the society, periodic loss of opportunities to spend free time in selected forms, deteriorating health condition). Considering environmental conditions is also a key issue in the diagnosis of the needs of elderly people with acquired visual impairment, as the extent and degree of negative effects of visual impairment will depend on the availability of individual and external resources.

The existing empirical analyses of support systems for senior citizens losing their vision has revealed a number of neglected areas in the area of early diagnosis of health problems, access to specialist ophthalmological treatment, and the provision of appropriate rehabilitation services. The multiplicity and complexity of the needs of this group of people requires active integration of clinical, social and therapeutic activities, but holistic care for senior citizens in numerous countries is still a desideratum ${ }^{28}$. Source analysis demonstrated that a significant percentage of elderly people experience visual problems that could potentially be eliminated or significantly reduced. These disorders remain undiagnosed for a number of reasons, among which the particularly common ones include:

- treating visual impairment as a natural consequence of ageing process combined with disbelief in the possibility of treatment and the achievement of a functional change,

${ }^{28}$ H. Court, G. McLean, B. Guthrie, S.W. Mercer, D.J. Smith, Visual impairment is associated with physical and mental comorbidities in older adults: a cross-sectional study, “BMC Medicine” 2014, no. 12(181), DOI: 10.1186/s12916-014-0181-7. 
- long waiting time for an ophthalmology appointment,

- lack of awareness of the adverse impact of visual impairment on everyday life,

- lack of information about available services, system limitations of specialist treatment,

- limited mobility which makes the access to healthcare facilities difficult 29 .

A small percentage of visually impaired people use private or public ophthalmic care services, and medical recommendations usually do not consider the specific nature of the functioning of elderly people. For example, multifocal glasses can reduce contrast sensitivity and depth perception, which negatively affects the ability of senior citizens to visually detect obstacles, thereby increasing the risk of falling, especially in unfamiliar surroundings ${ }^{30}$. It was observed that elderly people wearing multifocal lenses were twice as likely to fall compared to their peers wearing standard glasses ${ }^{31}$.

Organization of rehabilitation assistance including psychological therapy, learning alternative techniques for performing everyday activities, adaptation of the environment, training of spatial orientation and movement, social and recreational activation, constitutes another area of the system for supporting senior citizens who are losing their vision, which has profound deficiencies. The data collected by the Social Services Inspectorate showed that almost $50 \%$ of all departments of social services in the United Kingdom do not carry out assessments targeted at the needs of the elderly

${ }^{29}$ C. Bégin, V. Boudreault, D. Sergerie, La prévention des chutes dans un continuum de services pour les aînés vivant à domicile. Guide d'implantation - IMP - 2e édition, Institut National de Santé Publique du Québec, Québec 2009. J.M. Tielsch, J.C. Javitt, A. Coleman, J. Katz, A. Sommer, The Prevalence of Blindness and Visual Impairment among Nursing Home Residents in Baltimore, "The New England Journal of Medicine" 1995, no. 332(18), pp. 1205-1209.

${ }^{30}$ J.V. Odom, C.V. Odom, M.J. Leys, Does improving vision reduce the risk of falls? A review, "Insight: Research and Practice in Visual Impairment \& Blindness" 2011, no. 4(2), pp. 92-99.

31 S.R. Lord, S.T. Smith, J.C. Menant, Vision and falls in older people: risk factors and intervention strategies, "Clinics in Geriatric Medicine" 2010, no. 26(4), pp. 569-581. 
people with visual impairment, while the activities of specialists dealing with the distribution and monitoring of rehabilitation services do not in fact include this group of senior citizens. These negligence results from a number of reasons, among which the most important include:

- lack of knowledge of senior citizens about the possibility of formal registration as a person with visual impairment and the benefits in the field of services and social security resulting from obtaining this status,

- ineffective activities of teams of social workers (including lack of resources and specialized training, providing assistance based on a single, non-complex assessment of needs, no evaluation of services) $)^{32}$.

In the Polish aid system, there are also deficiencies in the number of centres and clinics, in which people who lose their full visual efficiency in late adulthood could receive specialist rehabilitation to facilitate adaptation to a new life situation. Therefore, despite its large size, this group relatively rarely uses the improvement of vision and other forms of visual impairment pedagogy-related support ${ }^{33}$. This problem particularly affects people living in rural areas and small towns.

In analyses conducted by the Royal National Institute for the Blind, it was noted that a significant percentage of elderly people with visual impairment primarily needs little support to be able to function at the level appropriate for their age group. In the meantime, social care institutions overloaded with work direct their help mainly to people who require significant support. Lack of relatively insignificant, but systematic help provided at home increases the risk of premature transfer of the senior citizen to a care institution,

$32 \mathrm{~J}$. Percival, Meeting the needs of older people with visual impairment: Social care or social exclusion? Thomas Pocklington Trust, London 2003, pp. 1-15.

${ }^{33}$ M. Dycht, Rehabilitacja optyczna osób starszych, [in:] "Niepełnosprawność w okresie późnej dorosłości”, ed. M. Kilian, E. Śmiechowska-Petrovskij, Oficyna Wydawnicza „Impuls”, Cracow 2018, pp. 248-252. 
which does not favour social activity of elderly people with this type of dysfunction ${ }^{34}$.

It should be remembered that the population of senior citizens with visual impairment reveals a significant degree of diversity, which suggests that many irregularities and neglects in the support system aimed at addressing the needs of this group of people have not yet been identified. The improvement of the quality of rehabilitation services certainly requires a reliable diagnosis of the current situation of elderly people who are losing their vision through transdisciplinary research investigating the experience of disability in terms of possessed resources and functional limitations as well as a specific social context. Support related activities should be planned in an integrated manner, considering the multiplicity of problems emerging during this period of life. This generates the need to intensify cooperation between specialists, in particular physicians, psychologists, social workers, vision rehabilitators, spatial orientation teachers and other experts operating in the field of broadly defined special geragogy.

The comprehensive nature of the activities is a necessary condition for achieving the basic goals of supporting elderly people with acquired vision disability, which are considered to be:

1) modification of misconceptions about the relationship of the experienced symptoms with the natural ageing process and the lack of possibility of an effective treatment,

2) reduction of the sense of uniqueness, isolation, loneliness and protection of mental health,

3) development new patterns of social functioning and a reasonable assessment of the current life situation ${ }^{35}$.

In the case of the population of elderly people with acquired visual impairment, the combination of rehabilitation services pro-

34 J. Percival, Meeting the needs of older people with visual impairment: Social care or social exclusion?, Thomas Pocklington Trust, London 2003, pp. 1-15.

35 S. Steuden, Poradnictwo psychologiczne dla osób w okresie późnej dorosłości, [in:] "Poradnictwo psychologiczne”, ed. Cz. Czabała, S. Kluczyńska, Wydawnictwo Naukowe PWN, Warsaw 2015, pp. 174-175. 
vided at home and participation in peer support groups is considered to be the most effective. Programs covering these two forms of services provide informational (broadening knowledge about the disease, as well as treatment and rehabilitation options) and emotional (reduction of mental tension felt in difficult situations) support, favour social contacts, strengthen the sense of self-determination and success in dealing with the consequences of vision loss ${ }^{36}$.

Community support is an economic solution that effectively prevents the institutionalization of these people. During home visits, basic assistance services are provided, including provision of assistance in performing self-care activities and household management, provision of reading services, provision of transport and guiding services. Specialized services usually offered by an educator of the visually impaired aim at teaching alternative techniques and new skills enabling the senior citizen to function independently. Home rehabilitation enables the acquisition of new competences at a pace adapted to the needs of elderly people with minimal disruption to daily routine, and without isolating the individual from their family and the local environment. Home visits allow for full individualization of the therapy process, both in terms of set goals and methods of their achievement. In turn, support groups favour the exchange of experiences and expression of emotions, and weaken the feeling of loneliness. Plans of a rehabilitation program for elderly people with acquired loss of vision or low vision must include the specific needs associated with the effects of ageing and individual interests, aspirations, habits. In general, in the first phase of work, therapeutic interactions focus on the help in emotional experiencing the trauma related to acquired dysfunction and the increase of independence by

36 A. Horowitz, R. Leonard, J.P. Reinhardt, Measuring psychosocial and functional outcomes of a group model of vision rehabilitation services for older adults, "Journal of Visual Impairment \& Blindness" 2000, no. 94(5), pp. 328-337. J. Kuczyńska-Kwapisz, M. Kilian, Rola grup wsparcia w podnoszeniu jakości życia niewidomych $i$ słabo widzacych osób w starszym wieku, [in:] "Jakość życia osób niepełnosprawnych i nieprzystosowanych społeczne", ed. Z. Palak, Wydawnictwo UMCS, Lublin 2004, pp. 101-107. 
training spatial orientation in the nearest surroundings ${ }^{37}$ as well as learning how to safely perform basic everyday activities ${ }^{38}$. Second come therapeutic goals related to the social and recreational phere ${ }^{39}$. Support of specialists for family members of an elderly person losing their vision is also necessary, because the family is still the basic entity providing daily care ${ }^{40}$, and its incorrect forms (e.g. excessive protection) may block the process of adaptation to the acquired dysfunction.

\section{Summary}

Despite the fact that as early as more than a decade ago people losing their fitness in late adulthood were indicated as a new subject for special education activities in Polish source literature, the interest in this group of people seems to be still insufficient, both in the scientific and research area and in the field of educational and rehabilitation practice. The lack of systematic aforementioned studies concerning these issues makes it difficult to make an unambiguous assessment of the state of satisfaction of rehabilitation needs of people acquiring visual impairment or low vision at elderly age. Based on the available data related to specific areas of this group's functioning, numerous fields that require the implementation of good practices that protect against social exclusion and favour successful ageing can be identified.

${ }^{37}$ J. Kuczyńska-Kwapisz, E. Śmiechowska-Petrovskij, Orientacja przestrzenna i poruszanie się osób z niepetnosprawnościa narządu wzroku. Wspótczesne techniki, narzędzia i strategie nauczania, Wydawnictwo Naukowe UKSW, Warsaw 2017, pp. 138-146.

${ }^{38}$ M. Kilian, Rehabilitacja $w$ zakresie poruszania się $i$ wykonywania codziennych czynności wobec potrzeb osób w starszym wieku z niepetnosprawnościa wzrokowa, "Człowiek - Niepełnosprawność - Społeczeństwo" 2009, no. 2(10), pp. 25-28.

${ }^{39}$ K.M. Ryan, Rehabilitation Services for Older People With Visual Impairments, "RE:view" 2002, no. 34(1), pp. 31-48.

${ }^{40}$ M. Rosochacka-Gmitrzak, Wsparcie opiekunów nieformalnych - w stronę równowagi społecznych oczekiwań i opiekuńczych możliwości rodzin, [in:] „Publiczna troska, prywatna opieka. Społeczności lokalne wobec osób starszych", ed. M. Racław, Fundacja Instytut Spraw Publicznych, Warszawa 2011, pp. 137-154. 
Furthermore, it seems necessary to undertake empirical analyses concerning ways of using the development potential of this group. The increase of the active participation of educators of the visually impaired and other specialists involved in activities for people with visual impairment is the key issue in developing a health care system and rehabilitation services for senior citizens, as well as integrated, interdisciplinary geriatric care. It is advisable to introduce systemic solutions enabling an increase in cooperation between non-governmental organizations which are currently the main entity offering rehabilitation services for adults losing their vision and health care and social care institutions. The gerontological education of society should also become a priority of the national policy for senior citizens, because the source of many difficulties experienced by senior citizens with disabilities is the negative stereotype of old age.

\section{Bibliography}

Alma M.A., Van Der Mei S.F., Melis-Dankers B.J.M., Van Tilburg T.G., Groothoff J.W., Suurmeijer T.P.B.M., Participation of the elderly after vision loss, "Disability \& Rehabilitation" 2011, no. 33(1), p. 63-72, DOI: 10.3109/09638288.2010.488711.

Bégin C., Boudreault V., Sergerie D., La prévention des chutes dans un continuum de services pour les aînés vivant à domicile. Guide d'implantation - IMP - 2e édition, Institut National de Santé Publique du Québec, Québec 2009.

Błachnio A., Potencjat osób w starości. Poczucie jakości życia w procesie starzenia się, Wydawnictwo UKW, Bydgoszcz 2019.

Court H., McLean G., Guthrie B., Mercer S.W., Smith D.J., Visual impairment is associated with physical and mental comorbidities in older adults: a cross-sectional study, "BMC Medicine" 2014, no. 12(181), DOI: 10.1186/s12916-014-0181-7.

Chrzanowska I., Pedagogika specjalna. Od tradycji do wspótczesności, Oficyna Wydawnicza „Impuls”, Cracow 2015.

Chrzanowska I., Starość z niepetnosprawnościa, [in:] „Człowiek i jego rodzina wobec utraty zdrowia i sprawności", ed. A. Nowicka, J. Bąbka, Copper Belt Technical College in Lubin, Lubin 2010, p. 91-111.

Czerwińska K., Kucharczyk, I., Nabycie niepetnosprawności wzroku w późnej dorostości a jakość życia, „Niepełnosprawność. Dyskursy pedagogiki specjalnej” 2019, no. 34, p. 131-145. 
Dryżałowska G., Kuleta-Hulboj M., Naumiuk A., Skura M., Steinhagen A.M., Inkluzja w perspektywie pedagogiki specjalnej i pedagogiki społecznej. Pytania, konteksty, dyskusje, Wydawnictwo UW, Warsaw 2018.

Dycht M., Rehabilitacja optyczna osób starszych, [in:] „Niepełnosprawność w okresie późnej dorosłości”, ed. M. Kilian, E. Śmiechowska-Petrovskij, Oficyna Wydawnicza "Impuls", Cracow 2018, p. 223-255.

Hairi N.N., Bulgiba A., Peramalah D., Mudla I., Do older people with visual impairment and living alone in a rural developing country report greater difficulty in managing stairs?, "Preventive Medicine" 2013, no. 56, p. 8-11.

Horowitz A., Leonard R., Reinhardt J.P., Measuring psychosocial and functional outcomes of a group model of vision rehabilitation services for older adults, "Journal of Visual Impairment \& Blindness" 2000, no. 94(5), p. 328-337.

Houde S.C. ed., Vision Loss in Older Adults. Nursing Assessment and Care Management, Springer Publishing Company, New York 2007.

Informacja o sytuacji osób starszych na podstawie badań Głównego Urzędu Statystycznego, https://stat.gov.pl/obszary-tematyczne/osoby-starsze/osoby-starsze/informa cja-o-sytuacji-osob-starszych-na-podstawie-badan-glownego-urzedu-statystycz nego,1,2.html [2 April 2019].

Kilian M., Następstwa utraty wzroku w starszym wieku, „Człowiek - Niepełnosprawność - Społeczeństwo" 2010, no. 2(12), p. 89-103.

Kilian M., Rehabilitacja w zakresie poruszania się i wykonywania codziennych czynności wobec potrzeb osób w starszym wieku z niepetnosprawnościq wzrokowa, "Człowiek Niepełnosprawność - Społeczeństwo” 2009, no. 2(10), p. 21-31.

Kościńska E., Starzenie się człowieka - zagadnienia ogólne, [in:] „Wybrane formy opieki i pomocy dla seniorów", ed. E. Kościńska, Wydawnictwo UKW, Bydgoszcz 2013, p. 11-33.

Krause A., Wspótczesne paradygmaty pedagogiki specjalnej, Oficyna Wydawnicza „Impuls", Cracow 2010.

Kuczyńska-Kwapisz J., Kilian, M., Rola grup wsparcia w podnoszeniu jakości życia niewidomych i stabo widzących osób w starszym wieku, [in:] "Jakość życia osób niepełnosprawnych i nieprzystosowanych społeczne", ed. Z. Palak, Wydawnictwo UMCS, Lublin 2004, p. 101-107.

Kuczyńska-Kwapisz J., Śmiechowska-Petrovskij E., Orientacja przestrzenna i poruszanie się osób z niepetnosprawnościq narządu wzroku. Wspótczesne techniki, narzędzia i strategie nauczania, Wydawnictwo Naukowe UKSW, Warsaw 2017.

Lewicka A., Niezależność osób niewidomych, czyli rzeczywistość - oczekiwania - utrudnienia, [in:] „Jakość życia a niepełnosprawność. Konteksty psychopedagogiczne", ed. Z. Palak, A. Lewicka, A. Bujnowska, Wydawnictwo UMCS, Lublin 2006, p. 365-368.

Lord S.R., Smith S.T., Menant J.C., Vision and falls in older people: risk factors and intervention strategies, "Clinics in Geriatric Medicine" 2010, no. 26(4), p. 569-581. 
Mandrzejewska-Smól I., Aktywność edukacyjna i zawodowa osób w wieku emerytalnym w perspektywie pomyślnego starzenia się. Diagnoza wybranych problemów, Wydawnictwo UKW, Bydgoszcz 2018.

Odom J.V., Odom C.V., Leys M.J., Does improving vision reduce the risk of falls? A review, "Insight: Research and Practice in Visual Impairment \& Blindness" 2011, no. 4(2), p. 92-99.

Pan C-W., Liu H., Sun H-P., Xu Y., Increased Difficulties in Managing Stairs in Visually Impaired Older Adults: A Community-Based Survey, “PLoS ONE” 2015, no. 10(11), DOI:10.1371/journal.pone.0142516.

Percival J., Meeting the needs of older people with visual impairment: Social care or social exclusion? Thomas Pocklington Trust, London 2003.

Rakowska A., Transformacja pedagogiki specjalnej - próba interpretacji niektórych aspektów ewolucji, [in:] „Uwarunkowania i kierunki rozwoju pedagogiki specjalnej", ed. B. Antoszewska, Cz. Kosakowski, Wydawnictwo Adam Marszałek, Torun 2011, p. 7-14.

Rosochacka-Gmitrzak M., Wsparcie opiekunów nieformalnych - w stronę równowagi społecznych oczekiwań i opiekuńczych możliwości rodzin, [in:] „Publiczna troska, prywatna opieka. Społeczności lokalne wobec osób starszych", ed. M. Racław, Fundacja Instytut Spraw Publicznych, Warszawa 2011, p. 137-154.

Ryan K.M., Rehabilitation Services for Older People With Visual Impairments, "RE:view" 2002, no. 34(1), p. 31-48.

Rynkowska D., Rola opiekunów w procesie wsparcia podopiecznych w świetle działalności opiekuńczej Polskiego Czerwonego Krzyża, Wydawnictwo URz, Rzeszów 2019.

Sinclair A., Ryan B., Hill D., Sight loss in older people. The essential guide for general practice, The Royal National Institute of Blind People, London 2014.

Steuden S., Poradnictwo psychologiczne dla osób w okresie późnej dorosłości, [in „Poradnictwo psychologiczne”, ed. Cz. Czabała, S. Kluczyńska, Wydawnictwo Naukowe PWN, Warsaw 2015, p. 158-187.

Stevens-Ratchford R., Krause A., Visually Impaired Older Adults and Home-Based Leisure Activities: The Effects of Person-Environment Congruence, "Journal of Visual Impairment \& Blindness" 2004, no. 98(1), p. 14-27.

Tielsch J.M., Javitt J.C., Coleman A., Katz J., Sommer A., The Prevalence of Blindness and Visual Impairment among Nursing Home Residents in Baltimore, "The New England Journal of Medicine" 1995, no. 332(18), 1205-1209.

Wahl H., Heyl V., Psychosocial adaptation to age-related vision loss: A six-year perspective, "Journal of Visual Impairment \& Blindness" 2001, no. 95, p. 739-748.

Wieczorek A., Starość i starzenie się z punktu widzenia wspótczesnego doradcy - geragoga, [in:] „Wielowymiarowość poradnictwa w życiu człowieka”, ed. D. Kukla, Difin, Warszawa 2011, p. 401-431.

Woźniak Z., Programy i strategie polityki społecznej dla grup ryzyka. Przestanki, cele, narzędzia, praca socjalna, Difin, Warsaw 2019. 